\title{
MULTI-FACETED INDIAN COSMOPOLITANISM IN VIKRAM CHANDRA'S SACRED GAMES
}

\author{
Ms.M.Pradeepa, Ph.D.Research Scholar \\ Department of English, \\ Kongunadu Arts and Science College \\ Coimbatore-29, Tamilnadu, India
}

\author{
Dr.M.Priya, Associate Professor \\ Department of English \\ PSG College of Arts and Science \\ Coimbatore,Tamilnadu, India
}

\begin{abstract}
Sacred Games is a crime novel and detective story thriller. Sartaj Singh, a veteran and suspicious Bombay police officer, receives an anonymous call one morning. The voice echoed a promise for an opportunity to capture the powerfulyl and criminally overloaded gangster mafia of G-Company, Ganesh Gaitonde. There arises various tough circumstances those Chandra stresses in the novel which are vivid and natural. His exposition of drug circulation, gagster don system and sexual abuse is par excellent all through the novel. In accordance with these features Chandra depicted the plot as the novel displays an array and multiplicity of the modern Indian society in terms of nuclear terrorism, partition, glamour world, fake spiritual policies and the plights of widows as well. The article discusses the touch of these aspects from the novel.
\end{abstract}

\section{Keywords-Ganster, mafia, nuclear terrorism, partition, spirituality, glamour, Indian Society}

\section{INTRODUCTION}

The novel, Sacred Games was published by Penguin India in 2006. It is an epic kind story focusing on a Sikh police Inspector, Sartaj Singh and his examination and investigation of the suicided, mafia kingpin, Ganesh Gaitonde.

Ganesh Gaitonde dies in the early chapters of the novel however he tells his confessing story to Sartaj in the alternating chapters with deep emotions about his mobster lifestyle. Chandra portrays the city's (Bombay's) character by concentrating on other characters in the story. He uses Bombay (Mumbai) street slang in his writing, which at times sounds harsh and abusive. The novel moves through various channels of in-depth introspection of the changes visible in very big cities like Bombay which provide support many illegalities. Some of those activities and issues are discussed in the article.

\section{Nuclear Terrorism}

The narration of the story is planted in the backdrop of nuclear threat. The mafia king- God, Ganesh Gaitonde comes to know about the Guruji's plan of nuclear bomb blast. He builds a cubicle for him to protect from nuclear possibility while Sartaj Singh and Anjali Mathur, a RAW officer, follow up the forwards of the terrorists groups to hamper their plan of blowing up Bombay. They investigate with same state of mind and their findings lead them to a virtual nuclear holocaust and intensity of destroying the humanity.

The novel places the existence of militant and revolutionary outfit, Hizbuddeen. It is the militia of the final day, the $25^{\text {th }}$ day of the nuclear holocaust. Sartaj and Gaitonde talk about the destruction of the whole India starting from Bombay. Kalki Sena deals with the extension of the nuclear terrorism are getting ready for war. They wanted to set up a perfect nation according to the Hindu doctrines called the Ram Rajya. The holocaust flavours the partition problems from Bombay and begins to spread all over the country.

\section{Political Corruption}

The government officials use their powers for illegitimate private gain. Corruption demoralizes democracy and better governance subverting formal processes in politics. Public administration becomes inefficient and provides menial services to the people due to corruption.

Bipin Bhonsle, a kind of Rakshak candidate for the constituency of Morwade meets the ganglord, Gaitonde to win an election in his support. When Gaitonde asks him specifically about their ventures to root out corruption, he replies, "When the whole world is dirty, bhai, you have to get dirty to do any cleaning. We can't fight their money without tricks. Once we are in power, it will all be different. We will change everything" ( $S G$ 244). Bhonsle is ready to dissipate all his money to win and Gaitonde provides him the vital man power. This is the politicians' state of affairs in India where power and money matters.

In general, a gang-lord who is condemned of murder was out on parole and the police records may say that he is absconding meanwhile he is working on with his malevolent activities in Bombay city. The city's police officials have special underworld monthly allowances with clubs and dance bars. It is quite apparent in Parulkar's character in the novel. $\mathrm{He}$ has been getting money from Suleiman Isa, one of the mafia-lords to carry on his despicable and nefarious activities. The whole system has become corrupt altogether and spoils the Indian society.

\section{Partition Chronicle}

The process of dividing the Indian subcontinent is the partition of India. India got independence from the British rule in 1947. Muslim sections of India chiefly the northern India 
became the nation of Pakistan and the majority Hindu sections became the southern part of India. The land of Punjab being fertile and wealthy, calmness and equanimity prevailed among the Hindus \& Muslims. Neither of them wished to renounce the valuable land. As the border was drawn down the middle of the province between Lahore and Amritsar, people had to move from one side to another. This turned into a painful exercise for them. Many refugees were killed due to the fire set upon by the militants in trains.

The torture of partition was a distressed struggle faced by the family of Prabhjot Kaur (Nikki), Sartaj Singh's mother. They were deceived by Khudabaksh Shafi, Prabhjot's father's Muslim friend. He planned an ambush in order to own thir land and house of his friend. The family faced a lot of sufferings and hardship to re-establish the lost.

\section{Inter-Caste Marriages}

Love is the principal reason for inter-caste marriages. There are many policies and rules existing in India for marriages. When a man and woman love each other belonging to different social groups, an inter-caste marriage is done. In the event of parents' disliking towards such marriages, they drop out their relationship with their children.

In the novel, Gaitonde's friend and money lender, Paritosh Shah's daughter, Dipika wished to marry Prashant Haaralkar of Chembur. He was a dedicated student who attended the night college, had a permanent job and supported his mother and younger sister. Being unhappy, Paritosh Shah showed aversion towards the inter-caste marriage proposal of her daughter. Hence she was married to some other man but after two months she killed herself.

\section{Defensive Machinery}

The prime foreign intelligence agency of India is the Research and Analysis Wing (RAW). Anjali Mathur is the officer of the RAW wing. She deals and investigates the Gaitonide's case. The case is primarily of national security. She seeks Sartaj's help for her mission and this remains a secret between them. They experience a generalized threat insight and perception that some militant group could use a portable weapon in an urban area especially in the heart of the Bombay city.

\section{The Glamour World}

The world of glitz and glamour mesmerizes everyone. The glisten and shimmer of the glamour world appears only superficially while the life of its underbelly seems to have dark, dreadful and ugly side. The character of Jojo Mascarenas, a model coordinator in the novel, recommends models of various agencies. She sends the needy, young and beautiful girls to rich aspirants. She herself wanted to become an actor. Even though she went through many assignments, her luck favored only in the television world. She was exploited on the pretext of a role.

Zoya Mirza, a famous model, had to struggle herself to excel in the film world. To try her luck in Bombay she ran away from her house. She was sent to Gaitonde by Jojo. Gaitonde slept with her and she was funded by him in return.
He helped her in enhancing her beauty. He produced a film for her later on. Women exploitation is being continued ever since women were working and the exploitation and abuse have taken myriad forms now. Exploitation is seen at work place and domestic violence, psycho-sexual abuses are reaching alarming levels.

\section{Fake Spiritual Saints}

India is the home land of many spiritual leaders. Those leaders are also called as 'Godman' who drive people in the right path. Some spiritual leaders possessed supernatural powers and performed miracles. Some others dwell in fame owing to charity works. The Guruji in the novel is destined with the power of vision. Than serving the humanity he uses his energy in evil and sinister objects. He involves in nuclear terrorism and wants the Hindus to rule. His primary need is to destroy everything and believes in the formation of a new statehood based on idealistic principles of Hinduism.

\section{The World of Gangsters}

Bombay is not exceptional from the gangster operations. The novel exposes the gangster networking operations of G-company and S-company. Both of them wish to extend their supremacy and force in their territories. Their connection with political groups and police force make their tasks easier. The advanced technologies and weapons made their systems easy to operate. Gang-arms, weapons, bombs act according to their will and heat any time.

\section{The Plight of Widows}

From a long time, the women who were responsible for the death of their spouse are blamed and ostracized from the families in the Indian society. They have to take shelters in ashrams and centers. They are forced to a state of earning and standing on their feet and carve their own position. Similarly, Kartekar's wife, Shalini Katekar becomes a destitute after her husband's death. Her world turns upside down. She has to put up with the loss of her husband and take care of her two children. Instead of helping her, her relatives try to extract money and criticize her for her modern approach. She earnestly finds satisfaction in emancipating the poor women about general hygiene and health measures. She regains serenity, peace and confidence and tries to cope her life up with the changing times.

\section{CONCLUSION}

Indian society, as depicted in the novel is full of examples reflecting the coming changes in the modes and manners of people. The changes which bring out the betterment of the society are to be accepted readily whereas retrogressive and harmful changes are to be shunted out. Indian culture speaks aloud about the conventional tradition and custom like faith in God, superstitious beliefs, fasting rituals, yet those practices damage and promotes the divisions in society. They are needed to be avoided. Hence the individuals need to focus on those set of principles which are acceptable and justified. Vikram Chandra, thus handed us the 
novel with varied life styles, situations, divisions, thoughts and prevalence of the people of different strata in the underworld of Bombay representing the society of India.

\section{REFERENCES}

(1) Chandra, Vikram. "Sacred Games". Boston : Faber \& Faber, 2006.

(2) Prasannarajan, S. "Sacred Games by Vikram Chandra." India Today, PP.26-28, 2008.

(3) Lehan,Richard. "The City in Literature:An Intellectual and Cultural History".Berkely:University of California Press, 1998.

(4) Kirpal,Viney.ed.The Postmodern Indian English Novel:Interrogationg the 1980s and 1990s.Bombay:Allied Publishers, 1996. 